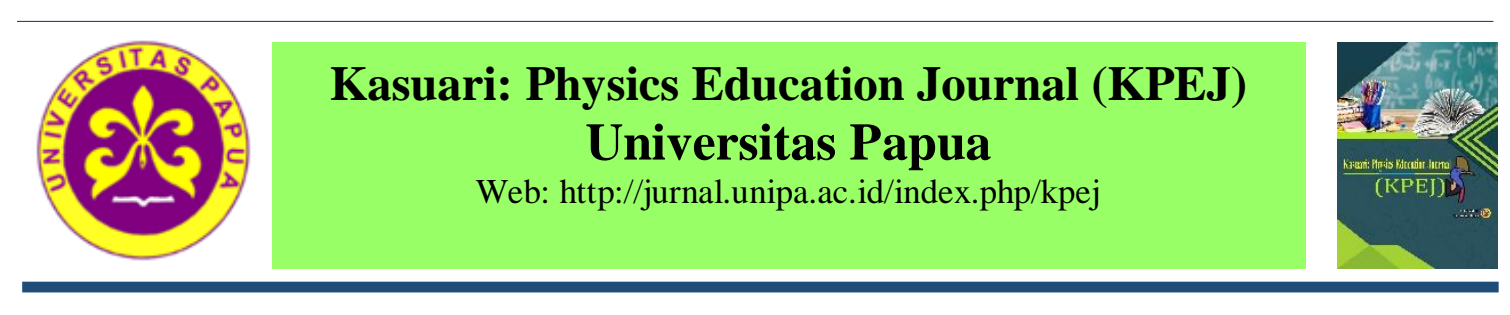

\title{
The Applicability of CNPs Worksheet for Measuring Students' Ability in Designing Experiment
}

\author{
Purwoko Haryadi Santoso ${ }^{1}$, Yusman Wiyatmo ${ }^{2}$ \\ ${ }^{1}$ Prodi Pendidikan Fisika, Universitas Sulawesi Barat, Majene 91413, Sulawesi Barat \\ ${ }^{2}$ Jurusan Pendidikan Fisika, Universitas Negeri Yogyakarta, Sleman 55281, Yogyakarta \\ *Corresponding author: purwokoharyadisantoso@unsulbar.ac.id
}

\begin{abstract}
This developmental research had developed two applicable curious note programs (CNPs) worksheets for quantifying student performances in designing experiment on newton law's of gravity. This study involved four developmental procedures of Thiagarajan's 4-D model. The CNPs worksheet was pilot tested in 3 groups of students at Yogyakarta's public school. It included 22 students for the pilot group and 60 students for the implement group. Our initial step of this developmental project had designed applicable CNPs worksheet based on acceptable CVI values, reliable measured results, and positive feedbacks from the user in both worksheets. Using this instrument, this study had revealed some interesting findings that our participants still discovered some difficulties in performing this kind of scientific abilities. Meanwhile, this study has recommended CNPs worksheet for the physics education communities as a convincing tool for measuring students' ability in designing physical experiment.
\end{abstract}

Keywords: designing experiment, worksheet, CNPs, scientific ability

\section{Kelayakan lembar kerja CNPs untuk mengukur kemampuan siswa dalam merancang eksperimen}

\begin{abstract}
Abstrak: Penelitian pengembangan ini telah mengembangkan dua lembar kerja curious note programs (CNPs) yang layak untuk mengukur kemampuan siswa dalam merancang eksperimen pada topik hukum gravitasi Newton. Penelitian ini melibatkan prosedur pengembangan yang mengikuti model 4-D Thiagarajan. Instrumen lembar kerja CNPs telah diujicobakan secara terbatas pada tiga kelompok di suatu sekolah negeri di Yogyakarta melibatkan 22 siswa untuk kelompok uji terbatas dan 60 siswa untuk uji implementasi. Tahap awal kami dalam penelitian pengembangan ini telah merancang lembar kerja CNPs yang layak berdasarkan nilai CVI yang dapat diterima, hasil pengukuran yang reliabel, dan tanggapan balik positif dari pengguna lembar kerja ini. Dengan menggunakan instrumen ini, penelitian ini telah menemukan beberapa hasil temuan yang menarik bahwa peserta uji coba masih menemukan beberapa kesulitan dalam melaksanakan jenis kemampuan saintifik ini. Meskipun demikian, penelitian ini telah merekomendasikan lembar kerja CNPs untuk komunitas pendidikan fisika sebagai alat yang cukup menjanjikan dalam mengukur kemampuan siswa untuk merancang eksperimen fisika.
\end{abstract}

Kata kunci: kemampuan saintifik, lembar kerja, CNPs, merancang eksperimen

\section{PENDAHULUAN}

Diinisiasi sekitar 8 tahun yang lalu, Kementerian Pendidikan dan Kebudayaan (Kemendikbud) Republik Indonesia telah mencanangkan suatu reformasi kurikulum 2013 untuk sekolah menengah dalam rangka mendukung tercapainya tujuan pendidikan nasional yang diamanatkan oleh Undang-Undang Dasar (UUD) 1945. Kurikulum 2013 diubah berdasarkan fondasi teoritik yang menyarankan dua arahan yang bisa diinternalisasikan dalam proses pembelajaran fisika (Kementerian Pendidikan dan Kebudayaan, 2014). Arahan pertama berpendapat bahwa guru diharapkan mampu 
mendorong pembelajaran yang mengutamakan pendekatan proses daripada hasil meliputi kegiatan yang melibatkan komponen kelas dan komunitas sosial. Selanjutnya, siswa seharusnya memperoleh perlakuan yang disesuaikan dengan latar belakang, sifat, dan kompetensi yang dimiliki siswa dalam mengikuti pembelajaran fisika.

Hasil inkuiri awal dengan melakukan wawancara terstruktur terhadap salah satu guru fisika di SMA N 6 Yogyakarta (Ida, 45 tahun, pseudonym) mengakui bahwa penerapan awal kurikulum 2013 masih menemukan beberapa hambatan praktis untuk dapat diterapkan secara efektif dalam pembelajaran fisika (Oktasari et al., 2020). Ida mengakui bahwa sebenarnya telah sering melaksanakan pembelajaran fisika dengan pendekatan yang direkomendasikan oleh kurikulum 2013. Berdasarkan temuan ini, kita mungkin bisa mengasumsikan bahwa diterapkannya pendekatan yang dilakukan Ida merupakan salah satu harapan yang diamanatkan kurikulum 2013. Akan tetapi, Ida menyadari bahwa frekuensi pelaksanaan pendekatan ini masih sangat jarang dibandingkan dengan pendekatan pembelajaran langsung yang lebih mudah pada tahap perencanaannya pada beberapa topik fisika. Beberapa topik fisika di sekolah mungkin bisa memberikan kesan jika proses belajar fisika hanya terpusat pada konten pengetahuan, hal yang juga diakui oleh Ida sebagai guru yang telah bekerja selama 10 tahun pada lembaganya dimana dia bekerja (Triwulandari, 2020). Kita mungkin bisa menganggap bahwa kenyataan ini belum begitu sesuai dengan hakikat ilmu fisika yang menitikberatkan pada proses pencarian menemukan konsep seperti yang telah diamanatkan oleh Kurikulum 2013. Lebih lanjut lagi, kenyataan ini juga bisa menimbulkan pembelajaran fisika yang lebih terkesan cenderung dekat dengan formula matematis dan rumus-rumus (Widyaningsih \& Yusuf, 2019). Akibatnya, banyak peserta didik yang menganggap bahwa fisika adalah pelajaran yang sulit dan tidak berharga untuk dipelajari. Jika kenyataan ini masih terjadi secara terus menerus maka tidak mengherankan jika masih rendahnya minat peserta didik untuk belajar fisika dalam proses pendidikannya, yang ditunjukkan melalui perolehan nilai rata-rata Ujian Akhir Nasional untuk jenjang SMA/MA pada Tahun 2013 yang menampilkan bahwa mata pelajaran fisika memperoleh posisi dengan nilai rata-rata terendah kedua setelah mata pelajaran matematika (Kaniawati \& Ramalis, 2012). Dengan demikian, penelitian mengalamatkan masalah ini agar bisa diselesaikan melalui suatu proses awal pengembangan produk berupa bahan ajar fisika seperti lembar kerja peserta didik pada dengan menerapkan pendekatan yang diarahkan oleh kurikulum 2013.

Model pembelajaran yang diarahkan oleh kurikulum 2013 adalah dengan menggunakan pendekatan saintifik. Salah satu strateginya dilakukan dengan menerapkan metode pembelajaran inkuiri yang menggunakan pendekatan science process skill (Saparini et al., 2019). Beberapa hasil penelitian telah membuktikan bahwa model pembelajaran berbasis inkuiri mampu meningkatkan kemampuan saintifik fisika siswa (Allo \& Sebayang, 2019; Husnaini \& Chen, 2019; McBride et al., 2004; McDermott et al., 2000). Salah satu pendekatan yang sejalan dengan pembelajaran inkuiri adalah model pembelajaran Curious Note Programs (CNPs) yang dikembangkan Park, et al (2009, p.1512). Model pembelajaran CNPs telah diujicobakan di salah satu sekolah negeri di Korea (Farumananda et al., 2018) dan telah dibuktikan bahwa lembar kerja CNPs mampu mendorong siswa dalam akitivitas kegiatan inkuiri secara aktif. Selama proses pembelajaran, peserta didik terlibat dalam aktivitas inkuiri untuk merangsang kemampuan saintifik seperti menemukan masalah, merancang eksperimen, merumuskan hipotesis, menyusun dasar teori, dan melaksanakan eksperimen.

Akan tetapi, dari keenam fase pembelajaran yang direncanakan dalam model pembelajaran CNPs, Park, et al (2009) menemukan bahwa langkah merancang eksperimen merupakan kegiatan tersulit yang akan dialami peserta didik dalam proses 
inkuiri ilmiah. Hal ini mungkin bisa disebabkan karena keterbatasan tingkat kognitif peserta didik pada tingkat sekolah menengah yang masih belum mempunyai kemampuan yang cukup untuk merancang eksperimen. Lebih lanjut lagi, fenomena masih jarangnya pembelajaran berbasis eksperimen yang dilakukan oleh guru pada topik tertentu, seperti yang telah diakui Ida dalam proses wawancara, menyebabkan siswa masih belum begitu terbiasa dengan proses pelaksanaan eksperimen dimulai dari perencanaan hingga memperoleh kesimpulan. Padahal, kegiatan merancang eksperimen merupakan salah satu tahap inkuiri ilmiah yang menurut Park, et al (2009) merupakan tahap penting dalam peningkatan kemampuan peserta didik dalam inkuiri ilmiah yang diharapkan kurikulum 2013. Dengan demikian, penelitian ini berusaha mengatasi celah kesenjangan ini dengan mengembangkan suatu produk lembar kerja dengan menerapkan langkah-langkah yang disarankan oleh model CNPs terutama untuk mengatasi fase tersulit kegiatan merancang eksperimen yang pada akhirnya dapat digunakan untuk mengukur salah satu komponen kemampuan saintifik siswa ketika merancang eksperimen.

Beberapa dokumentasi literatur menunjukkan bahwa lembar kerja berbasis model pembelajaran inkuiri seperti CNPs telah banyak dikembangkan pada beberapa topik fisika dasar seperti kinematika (Putri et al., 2020), kelistrikan (Sasanti et al., 2017), dinamika (Ljianto et al., 2020), hingga termodinamika (Memori et al., 2020). Akan tetapi, menurut pengetahuan kami, masih terdapat ruang pengembangan pada topik fisika yang masih jarang dilirik untuk dikembangkan, salah satunya adalah hukum gravitasi Newton. Padahal, materi ini merupakan perluasan beberapa konsep yang mungkin sudah dipahami melalui lembar kerja yang sudah diteliti sebelumnya. Berdasarkan alasan tersebut, penelitian ini menentukan pilihan salah satu topik fisika SMA yaitu hukum gravitasi Newton untuk mengisi celah kekosongan pemahaman fisika siswa yang belum banyak dikaji oleh penelitian sebelumnya. Keterbatasan penyelidikan pada topik ini mungkin dapat disebabkan oleh karakteristik materi yang masih jarang dilaksanakan dengan pendekatan laboratorium (eksperimen), seperti yang diakui guru fisika seperti Ida dimana telah mengikuti tahap awal penelitian ini melalui wawancara terstruktur diatas. Padahal, kegiatan laboratorium, seperti yang sudah dijelaskan diatas harus bisa menyentuh seluruh topik fisika dalam kurikulum 2013.

Berdasarkan beberapa pertimbangan yang telah tersusun, penelitian ini telah berhasil mengembangkan dua lembar kerja CNPs yang layak untuk mengukur kemampuan merancang eksperimen fisika peserta didik, khususnya pada topik hukum gravitasi Newton. Selama proses pengembangan, peneliti telah menguji coba dan menyelidiki kelayakan lembar kerja CNPs dengan mengajukan dua pertanyaan penelitian yang akan dijawab melalui serangkaian proses penelitian dan pengembangan antara lain :

1. Bagaimana kelayakan lembar kerja CNPs pada materi hukum gravitasi Newton?

2. Sejauh mana lembar kerja CNPs mampu untuk mengukur kemampuan peserta didik dalam merancang eksperimen ?

Pada bagian selanjutnya yaitu METODE PENELITIAN akan dijelaskan prosedur pengembangan lembar kerja CNPs dan metode untuk menguji tingkat kelayakannya berdasarkan kriteria penilaian oleh ahli secara isi (analisis konten), tingkat reliabilitas, dan hasil respon peserta didik. Selanjutnya, pada bagian HASIL DAN PEMBAHASAN akan diuraikan tentang temuan data-data pendukung dalam mendeskripsikan kelayakan lembar kerja CNPs untuk mengukur kemampuan peserta didik dalam merancang eksperimen yang diakhiri dengan bagian keempat yaitu SIMPULAN untuk menggarisbawahi hasil temuan yang diperoleh dalam penelitian ini beberapa kelemahan yang dimiliki penelitian ini serta beberapa saran yang diajukan sebagai ruang untuk penelitian selanjutnya. 


\section{METODE PENELITIAN}

Penelitian ini merupakan serangkaian proses pengembangan produk lembar kerja CNPs hingga uji coba produk melalui tahapan yang diajukan oleh model 4-D (Define, Design, Develop, dan Disseminate) menurut Thiagarajan \& Semmel (1974). Selain mengembangkan lembar kerja CNPs pada topik hukum gravitasi Newton, peneliti juga mengembangkan rencana pelaksanaan pembelajaran (RPP) untuk memandu guru dan siswa menerapkan lembar kerja ini. Proses pengembangan produk dilakukan pada bulan Juli hingga Agustus 2014 yang selanjutnya diujicobakan pada semester gasal tahun ajaran 2014/2015. Waktu pelaksanaan penelitian bertepatan dengan semester ganjil tahun ajaran 2014/2015 yang bersesuaian dengan materi pokok bahasan hukum gravitasi Newton yang diajarkan pada semester ganjil.

Terdapat empat alasan peneliti memilih lokasi uji coba produk di SMA N 6 Yogyakarta. Pertama, predikat SMA N 6 Yogyakarta sebagai The Research School of Jogja (Oktasari et al., 2020; Triwulandari, 2020) sehingga menempatkan SMA N 6 Yogyakarta pada peringkat 6 dari 11 sekolah negeri di Kota Yogyakarta sehingga dapat dikategorikan sebagai sekolah yang termasuk pada tingkat kelas menengah. Predikat ini diharapkan dapat menjelaskan kepada kita bahwa inovasi pengembangan produk pembelajaran dalam penelitian ini dapat lebih mudah disesuaikan di lokasi penelitian. Selain itu, peserta didik SMA N 6 Yogyakarta juga memiliki siswa yang berasal dari berbagai etnik di Indonesia. Dengan demikian, peserta didik SMA N 6 Yogyakarta setidaknya mampu merepresentasikan peserta didik di Kota Yogyakarta dan sedikit gambaran peserta didik di luar kota Yogyakarta. Kedua, sekolah telah menyatakan secara terbuka untuk menerima peneliti mengumpulkan data uji coba produk lembar kerja CNPs. Oleh karena itu, diharapkan data kelayakan yang diperoleh dalam penelitian ini bisa dijamin kebasahannya karena tidak ada unsur keterpaksaan dari sumber data dimana peneliti mengumpulkan data. Ketiga, topik hukum gravitasi Newton yang dilaksanakan dalam artikel ini belum pernah diteliti pada subjek uji coba berdasarkan informan inkuiri awal penelitian ini. Terakhir, lokasi SMA N 6 Yogyakarta merupakan sekolah yang relatif mudah untuk ditempuh dari lokasi komunitas pendidikan fisika peneliti dalam hal jarak, transportasi, waktu, tenaga, dan biaya sehingga kebutuhan akomodasi penelitian ini dapat lebih mudah untuk dijangkau secara teknis.

Proses pengembangan produk lembar kerja CNPs pada topik hukum gravitasi Newton mengikuti langkah-langkah yang diajukan oleh Thiagarajan \& Semmel (1974) yang terdiri dari 4 tahap. Pertama, adalah tahap define atau pendefinisian. Tahap define dilakukan untuk menentukan dan mendefinisikan syarat-syarat model pembelajaran CNPs yang akan diterapkan dalam lembar kerja. Tahap ini meliputi analisis awal, analisis peserta didik, analisis tugas, analisis konsep, dan perumusan tujuan pembelajaran pada topik hukum gravitasi Newton. Dalam tahap ini akan diperoleh beberapa deskripsi tujuan pembelajaran yang disesuaikan dengan tujuan dikembangkannya lembar kerja CNPs dan kompetensi dasar hukum gravitasi Newton. Kedua, dilaksanakan tahap design atau perancangan. Tahap design dilakukan untuk menyusun rancangan awal lembar kerja CNPs beserta instrumen penelitiannya untuk mengevaluasi kelayakannya. Tahap kedua ini memiliki tiga Langkah kegiatan yaitu penyusunan instrumen penelitian, pemilihan media pembelajaran, dan pemilihan format produk

Ketiga, peneliti mengembangkan lembar kerja CNPs pada tahap develop, memeriksa kelayakan produk secara isi berdasarkan justifikasi dua ahli, dan mengujicobakan kelayakan produk di lapangan. Kami mengawali menyusun rancangan awal lembar kerja CNPs yang merupakan rancangan awal yang sudah disusun peneliti berdasarkan tujuan 
yang telah dirancang pada tahap sebelumnya. Kemudian, kami meminta penilaian 2 orang ahli meliputi dosen ahli dan guru fisika sebagai praktisi yang telah berpengalaman dalam menerapkan pedoman praktis kurikulum pendidikan fisika untuk menjustifikasi dan memperbaiki kelayakan lembar kerja CNPs yang dikembangkan secara isi. Jika konten lembar kerja sudah layak berdasarkan keputusan dua orang ahli maka dilakukan uji coba lapangan yang terdiri dari dua jenis yaitu uji coba terbatas (pilot test) dan uji coba luas. Hasil dari tahap ini adalah keputusan kelayakan isi dan beberapa masukankritik terhadap rancangan awal lembar kerja CNPs Penilaian dilakukan oleh dosen ahli serta guru fisika SMA yang menjadi tempat pengambilan data pada tahap uji coba terbatas dan uji coba lapangan beserta saran-saran perbaikan terhadap lembar kerja CNPs sebelum diujicobakan kepada siswa.

Subjek uji coba yang berpartisipasi dalam penelitian ini adalah tiga kelas peserta didik kelas XI SMA N 6 Yogyakarta yang terdistribusi dalam kelompok uji coba terbatas dan uji coba luas berdasarkan penentuan dengan teknik purposive sampling yaitu teknik penentuan sampel dengan pertimbangan khusus. Suatu kelas dipilih sebagai kelas uji coba terbatas dan dua kelas lainnya ditetapkan sebagai kelas uji coba lapangan. Pertimbangan pembagian peruntukkan kelas uji coba telah didiskusikan dengan guru sekolah (Ida, pseudonym) menyesuaikan dengan urutan jadwal pembelajaran yang sudah ditentukan oleh pengurus kurikulum sekolah. Kelas yang mendapatkan jadwal lebih awal akan dijadikan sebagai kelas uji coba terbatas. Hal ini bertujuan agar peneliti dapat menerapkan lembar kerja CNPs secara terbatas dan mengevaluasinya sebelum lembar kerja CNPs diterapkan pada tahap yang lebih luas untuk memeriksa kendala teknis selama di lapangan. Deskripsi pembagian kelas uji coba terbatas dan uji coba luas dapat dilihat pada Tabel 1.

Tabel 1. Pembagian Kelompok Uji Coba

\begin{tabular}{|c|c|c|}
\hline Kelompok & Kelas & Ukuran \\
\hline Uji coba terbatas & XI-MIA 3 & 22 \\
\hline \multirow{2}{*}{ Uji coba luas } & XI-MIA 1 & 29 \\
\cline { 2 - 3 } & XI-MIA 2 & 31 \\
\hline
\end{tabular}

Uji coba terbatas ini dapat dilakukan untuk memperbaiki rancangan awal lembar kerja CNPs jika masih terdapat kekurangan dan kelemahan selain dari saran perbaikan kedua ahli. Selain itu, hasil uji coba terbatas juga digunakan sebagai sarana untuk memperoleh data empirik tentang tingkat reliabilitas lembar kerja CNPs dalam mengukur kemampuan merancang eksperimen peserta didik. Hasil uji empirik pada saat uji coba terbatas akan memperbaiki versi lembar kerja CNPs sebelum diujicobakan pada dua kelompok selanjutnya. Jika masih ada kekeliruan atas kendala teknis yang ditemukan pada saat uji coba terbatas kemudian peneliti akan memperbaiki kembali versi lembar kerja sebelumnya dengan segera. Hasil revisi terakhir lembar kerja CNPs setelah diujicobakan secara terbatas merupakan produk yang sudah siap untuk diujicobakan pada dua kelas XI MIA 1 dan XI MIA 2. Tahap uji coba lapangan dilakukan untuk menerapkan lembar kerja CNPs yang telah dikembangkan dalam skala yang lebih luas yaitu di 2 kelas yang berbeda dengan kelas uji terbatas. Tujuan lainnya adalah untuk mengukur tingkat kemampuan peserta didik di lokasi uji coba dalam merencanakan eksperimen dalam rangka menjawab pertanyaan kedua penelitian ini. Uji coba lapangan juga ditujukan untuk melihat hasil pengerjaan lembar kerja CNPs, respon peserta didik terhadap lembar kerja CNPs, serta keterlaksanaan pembelajaran CNPs. Hasil kinerja peserta didik pada lembar kerja CNPs digunakan untuk menentukan tingkat reliabilitas lembar kerja CNPs 
yang ditentukan berdasarkan nilai Percentage of Agreement (PA) dan Interclass Correlation Coefficient (ICC) yang diajukan oleh Bartko (1966) sehingga mampu mendeskripsikan tingkat kemampuan peserta didik dalam merancang eksperimen.

Keempat, tahap diseminasi. Tahap ini dilakukan dengan mencetak produk akhir lembar kerja CNPs menjadi lembar kerja final yang tersusun rapi dan dilengkapi cover, kata pengantar, dan daftar isi. Lembar kerja CNPs yang sudah tercetak kemudian dikemas yang siap untuk digunakan dan didistribusikan, beberapa tampilan akhir dari lembar kerja CNPs dapat dilihat pada Gambar 1. Selain itu, penyebaran pada tahap ini juga dilakukan dengan mempresentasikan produk akhir lembar kerja CNPs pada seminar nasional, lokakarya, atau workshop yang berkaitan dengan tema pendidikan fisika. Kami mengakui bahwa kegiatan diseminasi yang dilakukan tidak dapat dikategorikan sebagai proses diseminasi yang seluas-luasnya selayaknya hakikat arti kata diseminasi itu sendiri. Peneliti menyisakan ruang untuk peneliti selanjutnya untuk dalam melanjutnya proyek pengembangan lembar kerja CNPs atau bentuk bahan ajar lain sehingga secara bertahap hasil perkembangan ini dapat diterima oleh masyarakat pendidikan fisika yang lebih luas.
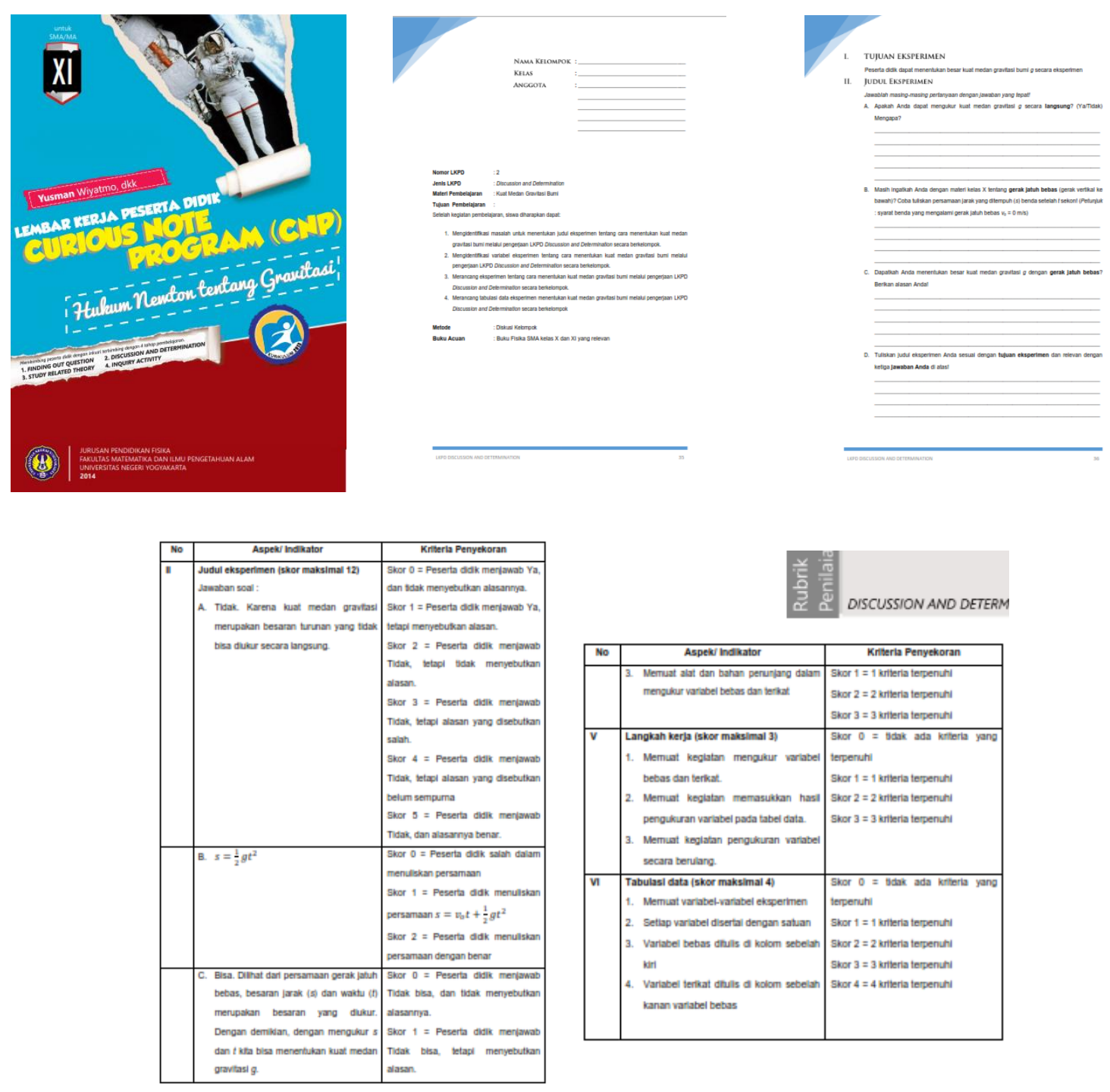

Gambar 1. Konten lembar kerja CNPs pada topik hukum gravitasi Newton 
Secara kuantitatif, data yang dikumpulkan untuk menjawab dua pertanyaan penelitian kami adalah data kelayakan lembar kerja CNPs dan data pengukuran kemampuan merancang eksperimen peserta didik. Instrumen yang digunakan untuk mengumpulkan data pertama antara lain angket penilaian ahli, angket respon peserta didik, dan lembar observasi keterlaksanaan RPP. Instrumen penelitian ini diadaptasi dari beberapa hasil penelitian dan telah memastikan bahwa alat ukur telah valid dan reliabel secara psikometrik untuk menilai lembar kerja CNPs secara isi. Selain mengembangkan instrumen pengumpulan data, kami juga mengembangkan perangkat pembelajaran berupa RPP untuk memandu penerapan lembar kerja CNPs dalam proses pembelajaran. RPP yang dibuat telah dikonsultasikan kepada ahli dan telah memenuhi tingkat percent of agreement (PA) (Borich, 2016, p.385) yang menunjukkan kualitas RPP yang dibuat. Selain nilai PA, nilai Interjudge Agreement (IJA) (Pee et al., 2002, p.580) juga telah digunakan untuk melihat kriteria lain dari kualitas RPP yaitu tingkat keterlaksanaannya dalam pembelajaran. Penelitian ini telah menemukan bahwa RPP CNPs yang telah memenuhi kriteria PA dan IJA yang baik.

Utamanya, instrumen penelitian mengumpulkan data kelayakan berupa penilaian ahli secara konten. Analisis kelayakan lembar kerja CNPs secara konten dilakukan dengan menerapkan persamaan Content Validity Ratio (CVR) dan Content Validity Index (CVI) oleh (Lawshe, 1975), yang mengikuti persamaan (1).

$$
C V R=\frac{\left(N_{e}-\frac{N}{2}\right)}{\frac{N}{2}}
$$

dimana,

$N_{\varepsilon} \quad=$ jumlah ahli yang menyatakan setuju

$N \quad=$ jumlah total ahli dalam panel penilaian

Setelah setiap butir pernyataan ditentukan nilainya, maka selanjutnya CVI akan menentukan rata-rata CVR dari setiap butirnya. Secara matematis, dinyatakan oleh persamaan (2).

$$
C V I=\frac{\text { jumlah seluruh } \text { CVR }}{\text { Jumlah butir angket }}
$$

Nilai CVI akan mendeskripsikan kelayakan lembar kerja CNPs secara isi. Kriteria yang digunakan dalam penelitian ini adalah nilai CVI yang diperoleh harus berada pada rentang lebih dari 0 (Lawshe, 1975). Kami mengakui bahwa dua penilai yang memutuskan kelayakan lembar kerja CNPs dalam penelitian ini seharusnya bisa melibatkan lebih banyak ahli minimal 3 orang seperti yang telah disarankan oleh Lawshe (1975). Kesimpulan yang diperoleh dalam penelitian ini mungkin masih perlu dievaluasi hasilnya, sebagai contoh dengan menambah jumlah panel ahli atau dengan menggunakan metode kuantisasi validitas konten seperti yang telah diajukan oleh Aiken (1985) atau yang lainnya.

Seperti yang telah dijelaskan sebelumnya, lembar kerja CNPs juga telah digunakan untuk mengukur kemampuan kinerja peserta didik dalam merancang eksperimen. Alat ukur yang baik harus memenuhi kriteria validitas dan reliabilitas yang baik. Paragraf sebelumnya telah menjelaskan prosedur penentuan kelayakan lembar kerja CNPs secara isi melalui analisis CVR yang dianalisis dengan menggunakan program SPSS versi 21. Selanjutnya, reliabilitas lembar kerja CNPs ditentukan berdasarkan analisis Interclass 
Correlation Coefficient (ICC) yang diajukan oleh Bartko (1966). Nilai ICC akan menunjukkan perbandingan antara nilai yang dihasilkan dari rater satu dengan rater yang lain.

Data yang terkumpul akan dianalusis secara deskriptif kuantitatif dengan mengkonversi data angket menjadi data kuantitatif melalui langkah-langkah menghitung rata-rata skor dari setiap komponen aspek penilaian RPP, mengkonversikan skor menjadi skala nilai 5, dan diakhiri dengan mencocokkan nilai tersebut dengan kategori kelayakan berdasarkan Tabel 2 berikut ini.

Tabel 2. Kategorisasi Hasil Penilaian Kelayakan

\begin{tabular}{|c|c|}
\hline Rentang & Kategori \\
\hline$X>4,26$ & Sangat Baik \\
\hline $3,42<X<4,26$ & Baik \\
\hline $2,58<X<3,42$ & Cukup Baik \\
\hline $1,74<X<2,58$ & Kurang Baik \\
\hline$X \leq 1,74$ & Sangat Kurang Baik \\
\hline
\end{tabular}

(Widoyoko, 2012, p. 238)

\section{HASIL DAN PEMBAHASAN}

Dalam penelitian ini, kami berusaha untuk menjawab dua pertanyaan penelitian yang telah diajukan di atas yaitu bagaimana kelayakan lembar kerja CNPs dan sejauh mana lembar kerja CNPs mampu mengukur kemampuan merancang eksperimen peserta didik. Kelayakan lembar kerja CNPs dijustifikasi berdasarkan penilaian oleh ahli dan praktisi secara isi, tingkat reliabilitas, dan hasil respon peserta didik setelah mengikuti pembelajaran hukum gravitasi Newton. Pertama, kami akan mendiskusikan tentang hasil penilaian kelayakan yang telah diperoleh dari ahli secara isi. Selanjutnya, akan dilihat berdasarkan tingkat keajegan yang dimiliki oleh lembar kerja CNPs dan diakhiri dengan melihat respon peserta didik terhadap lembar kerja CNPs yang mereka terima pada saat uji coba terbatas dan luas.

Berdasarkan ketiga aspek penilaian dalam angket penilaian ahli, lembar kerja CNPs memperoleh nilai CVI sebesar 1 dimana nilai ini masuk kategori sangat baik berdasarkan kriteria yang diajukan oleh Lawshe (1975). Kemudian, berdasarkan tingkat reliabilitas, lembar kerja CNPs memperoleh nilai ICC sebesar 0,952 secara rata-rata antara kedua produk yang bermakna bahwa lembar kerja CNPs sudah reliabel dalam kategori istimewa. Selanjutnya, kami juga mempertimbangkan aspek respon peserta didik terhadap lembar kerja CNPs yang dikembangkan. Ditemukan bahwa lembar kerja CNPs memperoleh respon peserta didik sebesar 0,82 (sangat baik). Angka ini menunjukkan bahwa lembar kerja CNPs diasumsikan telah berhasil membimbing peserta didik dalam belajar fisika dengan metode inkuiri ilmiah dalam membahas suatu rancangan eksperimen yang akan dilakukan pada topik hukum gravitasi Newtonyang meliputi kegiatan menentukan judul eksperimen, mengidentifikasi variabel, menentukan alat dan bahan, menyusun langkah kerja, dan merancang tabulasi data. Adapun hasil penguasaan kemampuan merancang eksperimen peserta didik SMA N 6 Yogyakarta disajikan dalam bentuk pie chart pada Gambar 2. 


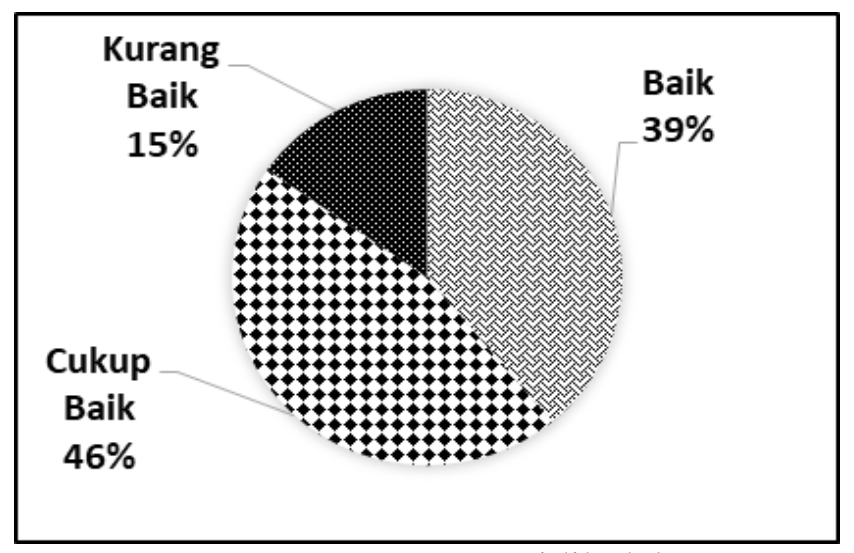

Gambar 2. Penguasaan Kemampuan Peserta Didik dalam Merancang Eksperimen

Sebagian besar peserta didik atau sebanyak $46 \%$ responden ( 82 siswa) memiliki kemampuan merancang eksperimen pada tingkat cukup baik. Sedangkan sisanya sebanyak $39 \%$ pada tingkat baik dan $15 \%$ pada tingkat kurang baik secara berturut-turut. Hal ini mengimplikasikan bahwa peserta didik tingkat sekolah menengah khususnya yang menjadi responden uji coba lembar kerja CNPs menunjukkan jumlah siswa dengan kemampuan merancang eksperimen pada tingkat "baik" masih lebih sedikit dibandingkan dengan siswa yang tergolong "cukup baik". Hasil ini dapat menggambarkan bahwa peserta didik sebenarnya belum begitu mampu dalam menguasai aspek-aspek kemampuan merancang eksperimen yang diujikan dalam lembar kerja CNPs (Farumananda et al., 2018). Hal ini juga bersesuaian dengan yang dinyatakan Park, dkk (2009) yang menyebutkan bahwa fase merancang eksperimen merupakan tahap tersulit yang akan dialami peserta didik dalam proses inkuiri ilmiah. Padahal, Park, et al (2009: 1512) telah memilih subjek uji coba lembar kerja CNPs di sekolah dimana peserta didik Korea yang masuk dalam kategori berkemampuan lebih dari peserta didik biasa (gifted youth). Akan tetapi, peserta didik dengan tingkat gifted youth saja masih menyebutkan bahwa fase kegiatan merancang eksperimen, fokus penelitian ini, merupakan fase tersulit bagi peserta didik. Sehingga, kenyataan ini merupakan masalah yang masih ditemukan hingga saat ini pada kegiatan inkuiri ilmiah tingkat sekolah menengah dimana sebagian besar siswa masih masih memiliki kemampuan merancang eksperimen dalam tingkat "cukup baik". Dengan demikian, beberapa hasil penelitian selalu menyarankan penelitian berkelanjutan untuk meningkatkan efektivitas pendekatan inkuiri ilmiah dalam mendukung suksesnya pendekatan saintifik versi Kurikulum 2013 (Husnaini \& Chen, 2019; Memori et al., 2020; Sasanti et al., 2017).

Hasil penelitian ini memiliki implikasi kepada peneliti atau pendidik ilmu fisika agar senantiasa mengevaluasi kegiatan pembelajaran fisika sehingga proses pembelajaran fisika di masa depan yang melibatkan guru, pendidik, hingga pengelola lembaga pendidikan dapat berjalan lebih efektif, khususnya untuk memenuhi harapan yang diamanatkan kurikulum pada pembelajaran inkuiri ilmiah. Proses ini merupakan perjalanan atau proses yang berjangka panjang tentunya membutuhkan usaha kita bersama-sama yang berkecimpung dalam dunia pembelajaran fisika untuk bekerja bersama-sama dan bahu-membahu dalam kolaborasi produktif. Dukungan antara komponen sekolah dan komponen peneliti physics education research (PER) harus dibangun dalam memperbaiki kualitas pembelajaran fisika khususnya pada bidang pembelajaran inkuiri ilmiah. Selain itu, penulis menyadari bahwa hasil penelitian ini masih tidak mampu mewakili kemampuan merancang eksperimen sekolah menengah di seluruh wilayah sekolah Indonesia berdasarkan beberapa keterbatasan yang masih 
dimiliki dalam penelitian ini. Pertama, hal yang disebabkan karena secara kualitatif ukuran subjek uji coba yang digunakan dalam penelitian ini masih sangat kecil dan bahkan kategori sekolah yang dipilih merupakan standar sekolah yang memiliki masukan siswa yang berasal dari lokasi pendidikan terbaik di Indonesia, meski ada beberapa siswa di luar daerah sekolah uji coba. Kedua, kelayakan ahli yang diputuskan dalam penelitian ini mungkin bisa digoyahkan ketika jumlah ahli menjadi lebih banyak yang berpartisipasi dalam memutuskan kelayakan isi lembar kerja menurut literatur Lawshe (1974). Ketiga, penelitian ini hanya fokus pada satu topik materi fisika yaitu hukum gravitasi Newton, yang sama sekali belum bisa mewakili keseluruan bidang keilmuan fisika yang dipelajari dalam kurikulum yang diterapkan. Oleh karena itu, peneliti menyadari bahwa masih terdapat ruang yang luas untuk penelitian selanjutnya misalkan bisa diujicobakan dalam ukuran sampel yang lebih banyak, menggunakan panel ahli yang lebih banyak, dan mempertimbangkan subjek uji coba yang lebih representatif untuk mewakili seluruh kemampuan sekolah menengah di Indonesia. Selain itu, penelitian ini juga tidak menggunakan studi terkontrol untuk menentukan efektivitas lembar kerja CNPs yang dikembangkan seperti yang telah dicapai pada penelitian pengembangan lembar kerja pada topik fisika lainnya seperti Ljianto et al. (2020). Alasan kedua ini merupakan pertimbangan peneliti yang pada akhirnya membatasi diri untuk mengajukan pertanyaan penelitian yang berhubungan dengan penyelidikan "efektivitas" kembar kerja CNPs ditinjau berdasarkan kriteria tertentu. Dengan demikian, saran terakhir kami untuk kesempatan penelitian selanjutnya adalah diharapkan dapat melaksanakan penelitian dengan desain studi terkontrol untuk menguji efektivitas lembar kerja CNPs yang dilaksanakan dalam durasi penelitian yang lebih lama dan ukuran subyek penelitian yang lebih banyak tentunya.

\section{SIMPULAN DAN SARAN}

Penelitian ini telah merekomendasikan instrumen untuk mengukur kemampuan siswa dalam merancang eksperimen melalui lembar kerja CNPs, khususnya pada materi hukum gravitasi Newton. Hasil uji coba dan penilaian ahli menyatakan bahwalembar kerja CNPs telah layak digunakan dalam komunitas penelitian pendidikan fisika berdasarkan kriteria penilaian konten, reliabilitas, dan respon peserta didik yang telah ditetapkan menurut literatur yang ada. Lembar kerja CNPs telah memenuhi kriteria instrumen yang layak untuk mengukur kemampuan merancang eksperimen peserta didik berdasarkan syarat alat ukur pendidikan yang baik untuk menyimpulkan kemampuan saintifik siswa. Dengan menggunakan lembar kerja CNPs, kemampuan merancang eksperimen peserta didik pada salah satu sekolah menengah yang menjadi subjek uji coba lembar kerja masih didominasi kelompok dengan tingkat kemampuan merancang eksperimen yang cukup baik, selanjutnya dipegang kelompok baik dan kurang baik secara bertutur-turut.

\section{DAFTAR PUSTAKA}

Aiken, L. R. (1985). Three coefficients for analyzing the reliability and validity of ratings. Educational and Psychological Measurement. https://doi.org/10.1177/0013164485451012

Allo, A. Y. T., \& Sebayang, S. R. B. (2019). The Implementation of Guided Discovery Learning Model Using Simple Tools. Kasuari: Physics Education Journal (KPEJ). https://doi.org/10.37891/kpej.v1i2.18

Bartko, J. J. (1966). The intraclass correlation coefficient as a measure of reliability. 
Psychological Reports. https://doi.org/10.2466/pr0.1966.19.1.3

Borich, G. D. (2016). Observation Skills for Effective Teaching. In Observation Skills for Effective Teaching. https://doi.org/10.4324/9781315633206

Farumananda, F. P., Wiyanto, M., \& Putra, N. M. D. (2018). The Development of Simple Harmonic Vibration Student Learning Worksheet (LKPD) based on Curious Note Program (CNP) Learning Model in Improving Students' Creative Thinking Ability. https://doi.org/10.2991/iset-18.2018.32

Husnaini, S. J., \& Chen, S. (2019). Effects of guided inquiry virtual and physical laboratories on conceptual understanding, inquiry performance, scientific inquiry self-efficacy, and enjoyment. Physical Review Physics Education Research. https://doi.org/10.1103/PhysRevPhysEducRes.15.010119

Kaniawati, I., \& Ramalis, T. R. (2012). ANALISIS PETA KOMPETENSI HASIL UJIAN NASIONAL SMA DI JAWA BARAT (Survey di Kota Bandung dan Kota Cimahi). Jurnal Pengajaran Matematika Dan Ilmu Pengetahuan Alam. https://doi.org/10.18269/jpmipa.v17i1.242

Kementerian Pendidikan dan Kebudayaan. (2014). Materi Pelatihan Implementasi Kurikulum 2013 Tahun 2014. Badan Pengembangan Sumber Daya Manusia Pendidikan Dan Kebudayaan Dan Penjaminan Mutu Pendidikan. https://doi.org/10.3406/arch.1977.1322

Lawshe, C. H. (1975). A Quantitative Approach to Content Validity. Personnel Psychology. https://doi.org/10.1111/j.1744-6570.1975.tb01393.x

Ljianto, L., Anita, A., \& Boisandi, B. (2020). Pengaruh Penerapan Lembar Kerja Siswa Berbasis Inkuiri Terbimbing Terhadap Kemampuan Metakognisi Siswa Pada Materi Hukum II Newton. Radiasi: Jurnal Berkala Pendidikan Fisika. https://doi.org/10.37729/radiasi.v13i2.295

McBride, J. W., Bhatti, M. I., Hannan, M. A., \& Feinberg, M. (2004). Using an inquiry approach to teach science to secondary school science teachers. Physics Education. https://doi.org/10.1088/0031-9120/39/5/007

McDermott, L. C., Shaffer, P. S., \& Constantinou, C. P. (2000). Preparing teachers to teach physics and physical science by inquiry. Physics Education. https://doi.org/10.1088/0031-9120/35/6/306

Memori, E. O., Darvina, Y., Syafriani;, \& Dewi, S. wahyuni; (2020). Validitas LKS Berbasis Problem Solving Dalam Meningkatkan Keterampilan 4C Pada Materi Termodinamika dan Gelombang Mekanik. Pillar of Physics Education.

Oktasari, D., Jumadi, Warsono, \& Putri, Z. R. (2020). Framework TPACK using Quick Response $(\mathrm{QR})$ code to promote ICT literacy students in learning physics. Journal of Physics: Conference Series. https://doi.org/10.1088/1742-6596/1567/3/032078

Pee, B., Woodman, T., Fry, H., \& Davenport, E. S. (2002). Appraising and assessing reflection in students' writing on a structured worksheet. Medical Education. https://doi.org/10.1046/j.1365-2923.2002.01227.x

Putri, W. N., Hidayati, H., \& Afrizon, R. (2020). Analisis Validasi Modul Fisika Bermuatan Literasi Saintifik pada Materi Gerak Lurus Dan Gerak Parabola. Pillar Of Physics ....

Saparini, S., Andriani, N., \& Pasaribu, A. (2019). Analysis of Science Process Skills for Student in Basic Physics Course. Kasuari: Physics Education Journal (KPEJ). https://doi.org/10.37891/kpej.v2i1.60

Sasanti, M., Hartini, S., \& Mahardika, A. I. (2017). Pengembangan LKS dengan model inquiry discovery learning (IDL) untuk melatihkan keterampilan proses sains pada pokok bahasan listrik dinamis. Berkala Ilmiah Pendidikan Fisika. 
Sivasailam Thiagarajan, Dorothy S. Semmel, and M. I. S. (1974). Instructional Decelopment For Training Teachers Of Exception Children. A Sourcebook ERIC.

Triwulandari, A. (2020). Pembelajaran Berbasis Project untuk Meningkatkan Prestasi Belajar Siswa di SMA Negeri 6 Yogyakarta. Jurnal Ilmiah WUNY. https://doi.org/10.21831/jwuny.v2i1.30943

Widoyoko, E. P. (2012). Teknik penyusunan instrumen penelitian. Yogyakarta: Pustaka Pelajar.

Widyaningsih, S. W., \& Yusuf, I. (2019). Project Based Learning Model Based on Simple Teaching Tools and Critical Thinking Skills. Kasuari: Physics Education Journal (KPEJ). https://doi.org/10.37891/kpej.v1i1.33 